\title{
PEMETAAN POTENSI OLAHRAGA REKREASI DI KABUPATEN BULELENG - BALI
}

\author{
Ade Hindhu Prastya ${ }^{1}$, Gede Hendri Ari Susila ${ }^{2}$ \\ 1,2 Jurusan Pendidikan Olahraga dan Kesehatan \\ Sekolah Tinggi Keguruan dan Ilmu Pendidikan Agama Hindu \\ Singaraja, Indonesia \\ email: siskamuff123@gmail.com, hendrimuff@yahoo.com
}

\begin{abstract}
Abstrak
Tujuan penelitian ini adalah untuk membuat deskripsi atau gambaran secara sistematis, faktual dan akurat mengenai potensi olahraga rekreasi di Kabupaten Buleleng. Pendekatan penelitian ini menggunakan penelitian deskriptif kualitatif eksploratif. Permasalahan yang dibahas dalam penelitian bertujuan untuk membuat deskripsi atau gambaran secara sistematis, faktual dan akurat mengenai fakta-fakta, sifat-sifat serta hubungan antar fenomena yang diselidiki yaitu potensi dan pengembangan olahraga rekreasi di Kabupaten Buleleng. Sasaran penelitian adalah kelompok masyarakat yang gemar akan olahraga rekreasi baik yang terdaftar dalam organisasi resmi atau tidak. Pada penelitian ini, pembagian 3 zone di kabupaten Buleleng dijadikan dasar dalam pengambilan sampel olahraga rekreasi, yaitu (1) sampel olahraga rekreasi yang berada di wilayah barat (Kecamatan Gerokgak, Kecamatan Seririt, Kecamatan Banjar, dan Kecamatan Busungbiu), keterwakilan sampelnya di Kecamatan Seririt; (2) sampel olahraga rekreasi yang berada di wilayah tengah (Kecamatan Buleleng, Kecamatan Sukasada), keterwakilan sampelnya di Kecamatan Buleleng; dan (3) sampel olahraga rekreasi yang berada di wilayah timur (Kecamatan Sawan, Kecamatan Kubutambahan, dan Kecamatan Tejakula), keterwakilan sampelnya di Kecamatan Kubutambahan. Pengumpulan data dalam penelitian ini menggunakan metode studi kepustakaan (LibraryStudy) dan penelitian lapangan (Field Reseach) dengan teknik observasi, wawancara dan dokumentasi. Pemeriksaan data menggunakan teknik triangulasi. Secara umum hasil pemetaan potensi olahraga rekreasi di kabupaten Buleleng dalam dirangkum sebagai berikut: (1) olahraga massal (senam orhiba, fun bike, fun run, gerak jalan, senam zumba) , (2) olahraga tradisional (megangsing, dagongan, hadang, terompah panjan, ergang, megoak-goakan), (3) olahraga khusus (senam lansia dan senam ling tien kung), dan (4) olahraga tantangan (airsoftgun, dayung, perahu layar, skateboard, arum jeram, dan kano).
\end{abstract}

Kata-kata kunci: pemetaan, potensi, olahraga rekreasi, buleleng.

\begin{abstract}
The purpose of this study was to a description or a systematic, factual and accurate description of the potensial of sport recreation in Buleleng Regency. This research approach uses descriptive qualitative exploratory research. The problems discussed in the study aim to make a description or a systematic, factual and accurate description of the facts, properties and relationships between the phenomena investigated. This phenomenon in this case is the potential and development of recreational sports in Buleleng Regency. Research targets are groups of people who love recreational sports,
\end{abstract}


whether registered or not. In this study, the division of 3 zones in Buleleng regency was used as the basis for sampling recreational sports, namely (1) recreational sports samples in the western region (Gerokgak District, Seririt District, Banjar District, and Busungbiu District), the sample representation in Seririt District ; (2) samples of recreational sports in the central region (Buleleng District, Sukasada District), the sample representation in Buleleng District; and (3) samples of recreational sports in the eastern region (Sawan District, Kubut adds District, and Tejakula District), the representation of the sample is in Kubutambah District. Data collection in this research uses the method of library study and field research with observation, interview and documentation techniques. Data checking uses triangulation technique. In general, the results of mapping the potential of recreational sports in Buleleng regency are summarized as follows: (1) mass sports (gymnastics, fun bike, fun run, walking, zumba gymnastics), (2) traditional sports (megangkas, dagongan, hadang, terompah panjan, ergang, megoak-goakan), (3) special sports (elderly gymnastics and ling tien kung gymnastics), and (4) challenge sports (airsoftgun, rowing, sailboats, skateboards, rafting, and canoeing).

Keywords: mapping, potential, sports recreation, buleleng.

\section{PENDAHULUAN}

Kehadiran Undang-Undang No. 3
tahun 2005 tentang Sistem Keolahragaan Nasional (SKN) diberlakukan, ada perubahan sebutan yang semula dikenal dengan nama "olahraga masyarakat" menjadi "olahraga rekreasi" menjadi dasar kuat berkembangannya olahraga rekreasi. Hal ini, tertuang di dalam pasal 17 yang membagi ruang lingkup olahraga menjadi 3 kegiatan, yaitu olahraga pendidikan, olahraga rekreasi, dan olahraga prestasi. Olahraga dan rekreasi erat hubungannya, apabila kata olahraga dan rekreasi digabungkan akan mengandung kata arti sendiri. Menurut Kusmaedi (2012:4) olahraga rekreasi merupakan olahraga yang dilakukan untuk tujuan rekreasi atau bersenangsenang. Selain itu juga Olahraga rekreasi adalah kegiatan fisik yang dilakukan pada waktu senggang berdasarkan keinginan atau kehendak yang timbul karena memberikan kepuasan dan kesenangan tersendiri.

Olahraga rekreasi dilakukan sebagai bagian dari proses kebugaran, kesehatan, dan kompetisi olahraga $\begin{array}{lll}\text { dimaksudkan } & \text { sebagai } & \text { upaya } \\ \text { meningkatkan } & \text { kualitas } & \text { hidup }\end{array}$ masyarakat. Pada pelaksanaan olahraga rekreasi, masyarakat dapat memilih beragam jenis olahraga yang sesuai dengan kegemarannya. Menurut Bandi Utama (2011: 12), mengatakan sated that sport is a king of game and physical activity which is done with agreat struggle against the self, the opponents, and the nature to reach winning. Pernyataan di atas dapat dimaknai bahwa olahraga merupakan raja dari permainan dan aktivitas fisik yang dilakukan dengan perjuangan hebat melawan diri sendiri dan alam untuk mencapai kemenangan. Menurut Toho (2011: 59) mengatakan secara langsung perkembangan olahraga rekreasi yang dikelola dengan baik dapat memberikan keuntungan yang besar pada masyarakat seperti: (1) memelihara kesehatan dan kondisi jasmani, (2)mendapatkan kesenangan/ kegembiraan/ kepuasan secara psikologi maupun psikis, (3) membentuk kebiasaan diri dalam menggunakan waktu untuk aktivitas fisik yang 
menyenangkan, dan (4) mencegah, mengetahui, dan mengkoreksi kelemahan jasmani.Federasi Olahraga Rekreasi Masyarakat Indonesia (FORMI) membagi lingkup olahraga rekreasi menjadi 4 bagian, meliputi: (1) Olahraga Massal yaitu kegiatan olahraga yang sebagian besar aktivitas fisiknya dilakukan dalam jumlah banyak; (2) Olahraga Tradisional merupakan permainan asli rakyat yang merupakan asset budaya bangsa yang memiliki unsur olah fisik tradisional dengan atau tampa sarana penunjang;(3) Olahraga Khusus adalah aktivitas fisik dengan mengkombinasikan gerak fisik dan pengaturan pernafasan dan diutamakan untuk kebutuhan gerak tubuh diusia lanjut; dan(4) Olahraga Tantangan merupakan aktivitas fisik yang kompleks dan cenderung menguji adrenalin.

Pemetaan Potensi olahraga rekreasi di Kabupaten Buleleng sangat dibutuhkan, mengingat kabupaten Buleleng memiliki 9 kecamatan yang memiliki potensi di pengembangan olahraga rekreasi. Menurut Jatmiko (2011: 59) Pemetaan merupakan proses penyajian informasi muka bumi yang fakta (dunia nyata), baik bentuk permukaan buminya maupun sumbu alamnya, berdasarkan skala peta, sistem proyeksi peta, serta simbol-simbol dari unsur muka bumi yang disajikan. Sedangkan pemahaman potensi menurut Sugiyono (2013: 409) merupakan segala sesuatu yang bila didayagunakan akan memiliki nilai tambah. Potensi dalam hal ini adalah potensi pada olahraga rekreasi. Pemetaan potensi olahraga rekreasi dapat memberikan tiga kontribusi utama, seperti: (1) penggunaan peta diharapkan memberikan gambaran deskriptif mengenai distribusi serta penyebaran olahraga rekreasi, (2) Keberadaan peta diharapkan dapat memberikan aspek prediktif penyebaran informasi terkait olahraga rekreasi, dan (3) Model interaktif, jika pada tahap dua, pola prediksi hanya sebatas ramalan kasus, tetapi jika menggunakan pendekatan interaktif, kita dapat menentukan intervensi serta dampaknya bagi masa depan dalam konteks perkembangan olahraga rekreasi.

\section{METODE}

Pendekatan penelitian ini menggunakan penelitian deskriptif kualitatif eksploratif. Metode penelitian kualitatif sering disebut metode penelitian naturalistik (Sugiyono, 2013:330). Permasalahan yang dibahas dalam penelitian bertujuan untuk membuat deskripsi atau gambaran secara sistematis, faktual dan akurat mengenai fakta-fakta, sifat-sifat serta hubungan antar fenomena yang diselidiki. Fenomena tersebut dalam hal ini adalah potensi dan pengembangan olahraga rekreasi di Kabupaten Buleleng. Sasaran penelitian adalah kelompok masyarakat yang gemar akan olahraga rekreasi baik yang terdaftar dalam organisasi resmi atau tidak dan selanjutnya berkembang sesuai dengan kebutuhan data. Pada penelitian ini, pembagian 3 zone dikabupaten Buleleng dijadikan dasar dalam pengambilan sampel olahraga rekreasi, yaitu (1) sampel olahraga rekreasi yang berada di wilayah barat (Kecamatan Gerokgak, Kecamatan Seririt, Kecamatan Banjar, dan Kecamatan Busungbiu). keterwakilan sampelnya di Kecamatan Seririt; (2) sampel olahraga rekreasi yang berada di wilayah tengah (Kecamatan Buleleng, Kecamatan Sukasada) keterwakilan sampelnya di Kecamatan Buleleng; dan (3) sampel olahraga rekreasi yang berada di wilayah timur (Kecamatan Sawan, Kecamatan Kubutambahan, dan Kecamatan Tejakula) keterwakilan 
sampelnya di Kecamatan

Kubutambahan. Pengumpulan data dalam penelitian ini menggunakan metode studi kepustakaan (LibraryStudy) dan penelitian lapangan (Field Reseach) dengan teknik observasi, wawancara dan dokumentasi. Pemeriksaan data menggunakan teknik triangulasi, teknik ini bersifat menggabungkan dari berbagai teknik pengumpulan data dan sumber data yang sudah ada, dengan cara: (1) mengkolaborasikan data hasil pengamatan dengan hasil wawancara, (2) mengkolaborasikan informasi yang didapat di depan umum dengan informasi yang dikatakan secara pribadi, (3) mengkolaborasikan informasi dari sudut pandang berbagai lapisan masyarakat, mengkolaborasikan hasil wawancara dengan isi suatu dokumen yang berkaitan. Prosesanalisis data kualitatif dimulai dari menelaah data yang terkumpul pada saat pengumpulan data. Kemudian langkah berikutnya adalah dengan mengadakan reduksi data yang dilakukan dengan jalan membuat abstraksi yaitu membuat rangkuman. Tahap selanjutnya adalah dengan melakukan keabsahan data, kemudian dilakukan penafsiran data dalam mengolah hasil sementara menjadi teori yang substantif.

\section{HASIL DAN PEMBAHASAN Hasil}

Potensi olahraga rekreasi di Kabupaten Buleleng yang diungkap berdasarkan hasil penelitian, dapat disajikan pada tabel di bawah ini.

Tabel 1. Potensi Olahraga Rekreasi di Kabupaten Buleleng

\begin{tabular}{|c|c|c|c|c|c|}
\hline \multirow[b]{2}{*}{ No } & \multirow{2}{*}{$\begin{array}{c}\text { Wilayah } \\
\text { Kabupaten } \\
\text { Buleleng }\end{array}$} & \multicolumn{4}{|c|}{ Kategori Olahraga } \\
\hline & & Massal & Tradisional & Khusus & Tantangan \\
\hline 1 & $\begin{array}{l}\text { Kecamatan } \\
\text { Seririt }\end{array}$ & $\begin{array}{l}\text { 1. Senam } \\
\text { Orhiba } \\
\text { 2. Fun Bike } \\
\text { 3. Fun Run } \\
\text { 4. Gerak } \\
\text { Jalan } \\
\text { 5. Senam } \\
\text { Zumba }\end{array}$ & $\begin{array}{l}\text { 1. Megangsing } \\
\text { 2. Dagongan } \\
\text { 3. Hadang } \\
\text { 4. Terompah } \\
\text { Panjang } \\
\text { 5. Egrang } \\
\text { 6. Megoak- } \\
\text { goakan }\end{array}$ & $\begin{array}{l}\text { 1. Senam Ling } \\
\text { Tien Kung } \\
\text { 2. Senam } \\
\text { Lansia }\end{array}$ & $\begin{array}{l}\text { 1. Airsoft Gun } \\
\text { 2. Dayung } \\
\text { 3. Perahu Layar } \\
\text { 4. Skateboard } \\
\text { 5. Panco } \\
\text { 6. Arum Jeram } \\
\text { 7. Kano }\end{array}$ \\
\hline 2 & $\begin{array}{l}\text { Kecamatan } \\
\text { Buleleng }\end{array}$ & $\begin{array}{l}\text { 1. Senam } \\
\text { Orhiba } \\
\text { 2. Fun Bike } \\
\text { 3. Fun Run } \\
\text { 4. Gerak } \\
\text { Jalan } \\
\text { 5. Senam } \\
\text { Zumba }\end{array}$ & $\begin{array}{l}\text { 1.Megoak- } \\
\text { goakan } \\
\text { 2.Dagongan } \\
\text { 3.Hadang } \\
\text { 4.Terompah } \\
\text { Panjang } \\
\text { 5.Egrang }\end{array}$ & $\begin{array}{l}\text { 1. Senam Ling } \\
\text { Tien Kung } \\
\text { 2. Senam } \\
\text { Lansia }\end{array}$ & $\begin{array}{l}\text { 1. Airsoft Gun } \\
\text { 2. Dayung } \\
\text { 3. Perahu Layar } \\
\text { 4. Skateboard } \\
\text { 5. Panco } \\
\text { 6. Kano }\end{array}$ \\
\hline 3 & $\begin{array}{l}\text { Kecamatan } \\
\text { Kubutambah } \\
\text { an }\end{array}$ & $\begin{array}{l}\text { 1. Senam } \\
\text { Orhiba } \\
\text { 2. Fun Bike } \\
\text { 3. Fun Run } \\
\text { 4. Gerak } \\
\text { Jalan } \\
\text { 5. Senam } \\
\text { Zumba }\end{array}$ & $\begin{array}{l}\text { 1. Dagongan } \\
\text { 2. Hadang } \\
\text { 3. Terompah } \\
\text { Panjang } \\
\text { 4. Egrang }\end{array}$ & $\begin{array}{l}\text { 1. Senam Ling } \\
\text { Tien Kung } \\
\text { 2. Senam } \\
\text { Lansia }\end{array}$ & $\begin{array}{l}\text { 1.Airsoft Gun } \\
\text { 2.Dayung } \\
\text { 3.Perahu Layar } \\
\text { 4.Skateboard } \\
\text { 5.Panco } \\
\text { 6.Banana Boat } \\
\text { 7.Kano }\end{array}$ \\
\hline
\end{tabular}




\section{Pembahasan}

Potensi olahraga rekreasi di Kabupaten Buleleng dibagi menjadi beberapa kategori sebagai berikut.

\section{Kategori olahraga massal}

Olahraga massal merupakan bentuk kegiatan olahraga yang aktivitasnya dilakukan dan diikuti banyak orang. Aktivitas olahraga massal sangat beragam dan memiliki karakteristik masing-masing. Hasil wawancara dibeberapa tempat seperti lapangan sepak bola Seririt (zone Buleleng Barat), taman kota Singaraja (zone Buleleng tengah), dan lapangan sepak bola Kubutambahan (zone Buleleng Timur) aktivitas senam massal sangat marak. Selain itu juga olahraga Senam Orhiba, Fun Bike, Fun Run, Senam Zumba, dan Gerak Jalan sangat terorganisir dengan baik. Khusus ketika memperingati hari tertentu seperti HUT Kota/Kemerdekaan RI.

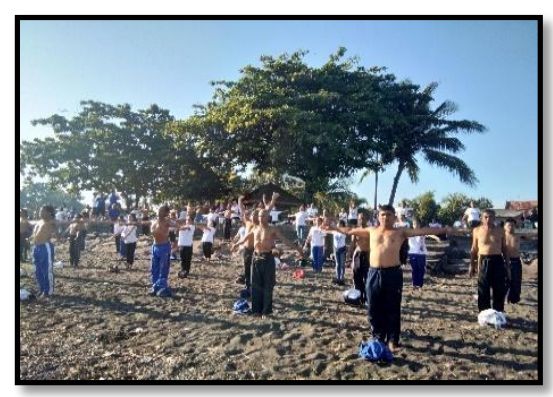

Gambar 1. Senam Orhiba

\section{Kategori olahraga tradisional}

Olahraga tradisional merupakan permainan rakyat yang dilakukan secara bersama-sama sejak dahulu kala dalam upaya mengisi waktu luang dan memanfaat sarana sederhanadan memiliki unsur olah fisik tradisional. Dalam perkembangannya setiap daerah memiliki permainan tradisional tersendiri, seperti permainan megangsing lebih populer di wilayah Buleleng Barat (contohnya Desa Umejero, Desa Bengkel, dll). Namun secara umum permainan tradisional dagongan, hadang, terompah panjang, egrang, dan megoak-goakan tersebar merata di wilayah lainnya di kabupaten Buleleng.

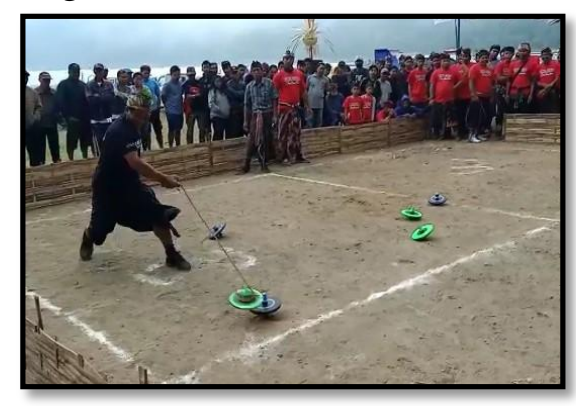

Gambar 2. Megangsing

\section{Kategori olahraga khusus}

Olahraga khusus merupakan kegiatan aktivitas fisik yang diperuntukan kepada kelompokkelompok khususnya seperti: kelompok usia atau keterbatasan fisik dan sejenisnya. Namun dalam pemetaan peneliti mengkhususkan kepada kelompok usia, sehingga hasil pemetaan olahraga khusus yang populer di kabupaten Buleleng adalah olahraga senam lansia dan senam ling tien kung. Karakteristik olahraga khusus ini menitikberatkan pada pengaturan pernafasan dan merileksasikan otot dengan gerakan yang sangat rileks.

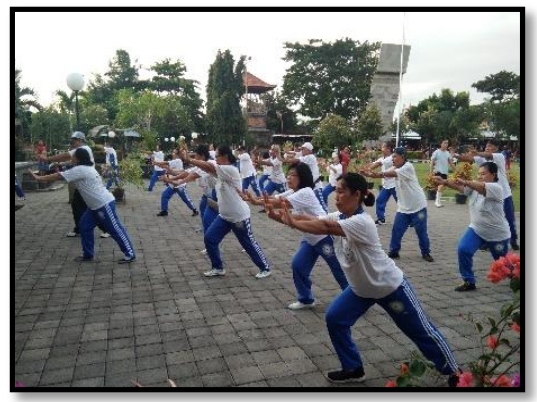

Gambar 3. Senam Ling Tien Kung

\section{Kategori olahraga tantangan}

Berbeda dengan kategori olahraga lainnya, olahraga tantangan memiliki ciri khas sendiri sesuai dengan namanya. Olahraga tantangan lebih mengarah pada pengujian ardenalin, 
memacu semangat, dan motivasi yang tinggi. Permainan airsoft gun, dayung, perahu layar, skateboard, panko, banana boat, dan kano merupakan jenis olahraga tantangan yang secara merata tersebar di kabupaten Buleleng dan memiliki eksistensinya tersendiri.

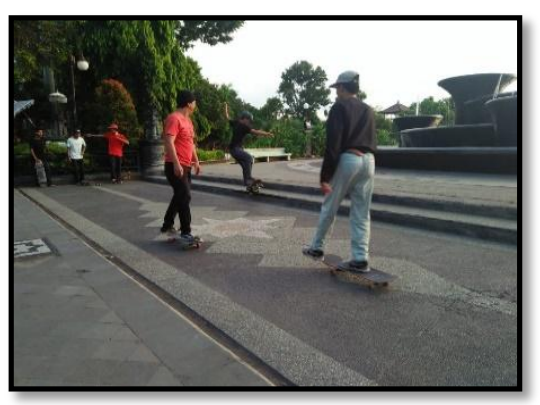

Gambar 4. Skateboard

Sejak terbentuknya FORMI Kabupaten Buleleng perkembangan olahraga rekreasi belum berjalan dengan baik, namun peran pemerintah kabupaten Buleleng untuk membangkitkan jenis olahraga rekreasi ini sudah terlihat jelas. Pelaksanaan kegiatan Buleleng Festival dan Twin Lake Festival Buyan dan Tamblingan merupakan indikator kebangkitan dari beberapa unsur dalam perkambangan olahraga rekreasi. Mengingat di dalam kegiatan tersebut kategori olahraga massal, olahraga tradisonal, olahraga khusus, dan olahraga tantangan mulai dipertandingkan.

\section{SIMPULAN}

Simpulan penelitian ini adalah sudah terpetakannya potensi olahraga rekreasi di kabupaten Buleleng. Secara umum kategori olahraga dibagi menjadi 4 bagian, seperti (1) olahraga massal, (2) olahraga tradisional, (3) olahraga khusus, dan (4) olahraga tantangan. Selain itu juga, terorganisir kelompokkelompok masyarakat dalam memilih jenis olahraga yang sesuai dengan kebutuhannya merupakan salah satu indikator pencapaian keberhasilan pemetaan potensi olahraga di kabupaten Buleleng.

\section{DAFTAR PUSTAKA}

Jatmiko, S. S. (2011). Pengembangan Peta Tiga Dimensi Interaktif Gedung Teknik Elektro Institut Teknologi Sepuluh Nopember Surabaya Menggunakan Unreal Engine. Undergraduate Thesis, Institut Teknologi Sepuluh Nopember, Surabaya.

Kusmaedi, Nurlan. (2012). Olahraga Lansia. Bandung: FPOK - UPI.

Sugiyono. 2013. Metode Penelitian Pendidikan. Bandung: Alfabeta.

Toho Cholik Muthohir, Muhamad Muhyi, dan Albertus Fenanlampir, 2011. Berkarakter dengan berolahraga berolahraga dengan berkarakter. Sport media.

Undang-undang Republik Indonesia No. 3 Tahun 2005 tentang Sistem Keolahragaan Nasional Bab IV pasal 17.

Utama Bandi,AM, 2011. Playing As The Beginning Of Sport Culture. Proceeding of The $3^{\text {rd }}$ International Seminar On Sport And Physical Education. "Striving For World Sport Achievements Through Sport and Physical Edication". Faculty of Sport Science, Yogyakarta State University Yogyakarta.ISBN 978-6028429-41-2. 